ARTICLE

Received 5 Nov 2013 | Accepted 22 Apr 2014 | Published 22 May $2014 \quad$ DOl: 10.1038/ncomms4937

\title{
Deactivation of carbon electrode for elimination of carbon dioxide evolution from rechargeable lithium-oxygen cells
}

Seok Ju Kang ${ }^{1}$, Takashi Mori², Satoru Narizuka², Winfried Wilcke ${ }^{1} \&$ Ho-Cheol Kim ${ }^{1}$

Carbon has unfaired advantages in material properties to be used as electrodes. It offers a low cost, light weight cathode that minimizes the loss in specific energy of lithium-oxygen batteries as well. To date, however, carbon dioxide evolution has been an unavoidable event during the operation of non-aqueous lithium-oxygen batteries with carbon electrodes, due to the reactivity of carbon against self-decomposition and catalytic decomposition of electrolyte. Here we report a simple but potent approach to eliminate carbon dioxide evolution by using an ionic solvate of dimethoxyethane and lithium nitrate. We show that the solvate leads to deactivation of the carbon electrode against parasitic reactions by electrochemical doping of nitrogen into carbon. This work demonstrates that one could take full advantage of carbon by mitigating the undesired activity.

\footnotetext{
${ }^{1}$ IBM Research-Almaden, 650 Harry Road, San Jose, California 95120, USA. ${ }^{2}$ Central Glass International, Inc., 2033 Gateway PI., Ste. 569 , San Jose, California 95110, USA. Correspondence and requests for materials should be addressed to S.J.K. (email: skang@us.ibm.com) or to H.-C.K.

(email:hckim@us.ibm.com).
} 
ithium-oxygen $\left(\mathrm{Li}-\mathrm{O}_{2}\right)$ batteries offer ultra-high energy storage that possibly eliminates the range anxiety of electric vehicles if realized ${ }^{1-4}$. For last several years, extensive studies on the $\mathrm{Li}-\mathrm{O}_{2}$ batteries with non-aqueous electrolytes have been performed by several research groups ${ }^{1,3,5-8}$. This allows us to understand the fundamentals of $\mathrm{Li}-\mathrm{O}_{2}$ chemistry and to identify the challenges facing for the successful operation of the $\mathrm{Li}-\mathrm{O}_{2}$ cells. To identify materials (in particular, electrolytes and cathodes) that are stable against parasitic reactions involved with active species in the cells (intermediates such as superoxides, discharge product such as $\mathrm{Li}_{2} \mathrm{O}_{2}$ ) is a paramount challenge. The formation and decomposition of byproducts originating other than net electrochemical reaction of $\mathrm{Li}-\mathrm{O}_{2}$ cells, $2\left(\mathrm{Li}^{+}+\mathrm{e}^{-}\right)+\mathrm{O}_{2} \leftrightarrow \mathrm{Li}_{2} \mathrm{O}_{2}\left(\mathrm{U}_{0}=2.96 \mathrm{~V}\right.$ versus $\left.\mathrm{Li} / \mathrm{Li}^{+}\right)$, lead to catastrophic degradation of the cells, resulting in poor rechargeability $6,8-11$.

The analysis of gas evolution during the operation of $\mathrm{Li}-\mathrm{O}_{2}$ cells has been crucial for learning the internal chemical processes $7,9,12$. In particular, the $\mathrm{CO}_{2}$ evolution during the charge cycle provides critical clues on the oxidative decomposition of byproducts, hence has been studied extensively. To date, no $\mathrm{Li}-\mathrm{O}_{2}$ cell with carbon cathode has shown cycleability without $\mathrm{CO}_{2}$ evolution, which indicates that the carbon plays a major role for the parasitic reactions ${ }^{7,9}$. This is unfortunate since the advantageous properties of carbon (such as light weight, low cost and so on), which have been beneficial to wide ranges of electrochemical cells ${ }^{13}$, will not be applicable to the $\mathrm{Li}-\mathrm{O}_{2}$ cells. Consequently, recent research effort undergoes for searching alternative materials to carbon such as nanoporous gold $(\mathrm{Au})$ and titanium carbide $(\mathrm{TiC})^{7,14}$. Although the reversible battery operation without $\mathrm{CO}_{2}$ evolution has been demonstrated with the alternative materials, applying them into $\mathrm{Li}-\mathrm{O}_{2}$ cells leads to significant trade-offs in the specific energy and cost, hence making them impractical. Carbon certainly has unfaired advantages in material properties to be used as an electrode if one could mitigate the undesired activity.

In this paper, we present an effective approach to deactivate carbon electrode using an ionic solvate of dimethoxyethane (DME) and lithium nitrate $\left(\mathrm{LiNO}_{3}\right)$. The interaction between the ionic solvate and active sites of carbon during the discharge process of $\mathrm{Li}-\mathrm{O}_{2}$ cells resulted in the formation of Pyridinic structure. The deactivation of carbon electrode leads to complete elimination of $\mathrm{CO}_{2}$ during the charge cycle, which implies the suppression of parasitic reactions associated with carbon electrode. This work enables rechargeable $\mathrm{Li}-\mathrm{O}_{2}$ cells without $\mathrm{CO}_{2}$ evolution by mitigating the undesired activity of carbon electrode.

\section{Results}

Elimination of $\mathbf{C O}_{2}$ evolution. The structural details of the $\mathrm{Li}-\mathrm{O}_{2}$ cell used in this study are presented schematically in Fig. 1a. A carbon black (Ketjenblack, KB) is used as the cathode material (see the methods section). The amount of $\mathrm{O}_{2}$ and $\mathrm{CO}_{2}$ gas evolved during the charge cycle of the cell was measured using a differential electrochemical mass spectrometry (DEMS). The analytical performance of our DEMS set-up has been discussed previously $^{12}$. The $\mathrm{Li}-\mathrm{O}_{2}$ cells were discharged up to the capacity of $1 \mathrm{mAh}(200 \mu \mathrm{A}$ and $5 \mathrm{~h})$, and the consumption of $\mathrm{O}_{2}$ was monitored by the pressure drop. During the charge cycle, the amounts and masses of gases evolved from the cell were analysed. The galvanostatic discharge and charge profiles of two $\mathrm{Li}-\mathrm{O}_{2}$ cells containing $0.5 \mathrm{M} \mathrm{LiNO}_{3}$-DME and $1 \mathrm{M}$ LiTFSI-DME electrolytes, respectively, are presented in Fig. 1b. While the discharge profiles of the two cells are very similar, the charge behaviour of the cells are noticeably different: the cell containing $0.5 \mathrm{M} \mathrm{LiNO}_{3}-\mathrm{DME}$ shows a plateau in charge potential while the cell with $1 \mathrm{M}$ LiTFSI-DME shows rapidly increasing potential with charging time throughout the entire range of charge cycle. The scanning electron microscopy (SEM) image in Fig. 1c presents the discharge products on carbon cathode of the cell containing $0.5 \mathrm{M} \mathrm{LiNO}_{3}$-DME. The well-defined toroidal nanoparticles of $\mathrm{Li}_{2} \mathrm{O}_{2}$ having diameters of $\sim 300-500 \mathrm{~nm}$ indicates that the main reaction in the cell is the $\mathrm{Li}-\mathrm{O}_{2}$ electrochemistry that generates $\mathrm{Li}_{2} \mathrm{O}_{2}$. The X-ray diffraction analysis confirms the formation of $\mathrm{Li}_{2} \mathrm{O}_{2}$ crystals during discharge process (Supplementary Fig. 1). In contrast, the cell with $1 \mathrm{M}$ LiTFSI-DME electrolyte shows no clear evidence for the growth of the toroidal nanoparticles (for $1 \mathrm{mAh}$ discharge), even though deposition of $\mathrm{Li}_{2} \mathrm{O}_{2}$ is evidenced by the gas analysis during charge cycle (Supplementary Fig. 2) ${ }^{15,16}$.

Figure 1d and e presents the DEMS results that render the direct comparison of the gas evolution from the two cells containing different electrolytes (that is, $0.5 \mathrm{M} \mathrm{LiNO}_{3}-\mathrm{DME}$ and $1 \mathrm{M}$ LiTFSI-DME). The $\mathrm{O}_{2}$ evolution from the cell with $0.5 \mathrm{M}$ $\mathrm{LiNO}_{3}$-DME electrolyte increases sharply at the beginning of the charge cycle and then stays constant throughout the entire charge cycle. No $\mathrm{CO}_{2}$ evolution was observed for this cell even at the later stage of the charge cycle. This behaviour was consistent regardless of the degree of discharge: the DEMS results of the cell discharged to the discharge cutoff potential of $2.0 \mathrm{~V}$ show no evidence of $\mathrm{CO}_{2}$ evolution as well (Galvanostatic discharge/ charge profiles and corresponding in situ DEMS results are shown in Supplementary Fig. 3). This behaviour is strikingly different from that of the cells containing other electrolytes. As shown in Fig. 1e, the DEMS result of the cell containing $1 \mathrm{M}$ LiTFSI-DME shows large amount of $\mathrm{CO}_{2}$ evolution and, coincidently, less amount of $\mathrm{O}_{2}$ evolution during the charge cycle. It is noted that the total amount of $\mathrm{O}_{2}$ evolved from the cell with $0.5 \mathrm{M} \mathrm{LiNO}_{3}$-DME electrolyte is $\sim 15 \%$ more than that from the cell containing $1 \mathrm{M}$ LiTFSI-DME electrolyte. To understand this unique behaviour of the $\mathrm{Li}-\mathrm{O}_{2}$ cell containing $\mathrm{LiNO}_{3}-\mathrm{DME}$ electrolyte, we carried out the impedance spectroscopy measurements at multiple points during discharge and charge cycles. Figure 1f shows the electrolyte resistance $\left(R_{\mathrm{s}}\right)$ as a function of capacity for discharge and charge. Interestingly, the $R_{\mathrm{s}}$ values of

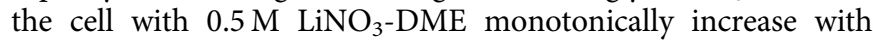
increasing discharge capacity, ranging from 44.3 to $58.0 \Omega$. During charge cycle, the $R_{\mathrm{s}}$ values decrease with charge time (which corresponds to the decrease in capacity from $1.0 \mathrm{mAh}$ ) until the cell potential reaches $3.7 \sim 3.8 \mathrm{~V}$. The $R_{\mathrm{s}}$ value shows some hysteresis at the end of charge cycle and remains $\sim 4 \Omega$ higher than the $R_{\mathrm{s}}$ at the beginning of discharge. In contrast, the $R_{\mathrm{s}}$ values for the cell containing LiTFSI-DME (shown in Fig. 1g) stay almost constant during the discharge and charge cycles. Since the number of conductive species (dominantly salt ions) in the electrolyte determines the $R_{\mathrm{s}}$ value, the changes in $R_{\mathrm{s}}$ with $\mathrm{LiNO}_{3}$ DME indicate that the number of conductive species decreases with discharge time and reversibly increases during charge cycle. There are some degrees of irreversible changes in the number of conductive species at the end of discharge/charge cycle, which results in the hysteresis in $R_{\mathrm{s}}$ value.

Deactivation of carbon cathode. Previously, experiments using the carbon isotope $\left(99 \%{ }^{13} \mathrm{C}\right)$ cathode have suggested that the carbon in the $\mathrm{CO}_{2}$ gas evolved from the cells is originating from both electrolyte and cathode ${ }^{9,12}$. The complete elimination of $\mathrm{CO}_{2}$ evolution presented in Fig. 1, therefore, indicates that the combination of $\mathrm{LiNO}_{3}$ salt and DME solvent plays a crucial role to interrupt the parasitic reactions that are involved with both cathode and electrolyte. To elucidate the details behind this $\mathrm{CO}_{2}$-evolution-free charging behaviour, we performed sets of 
a

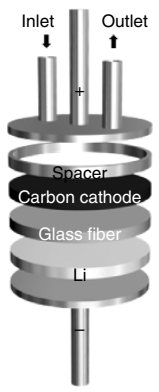

b

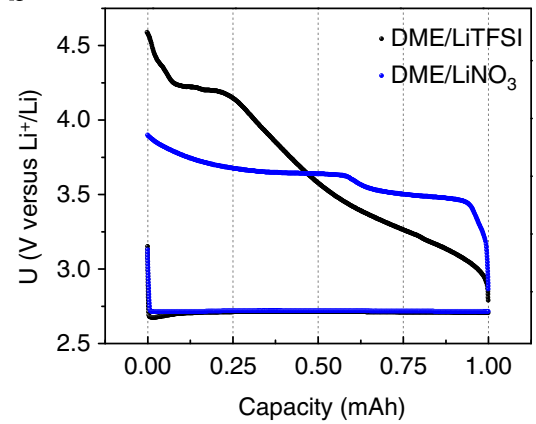

d

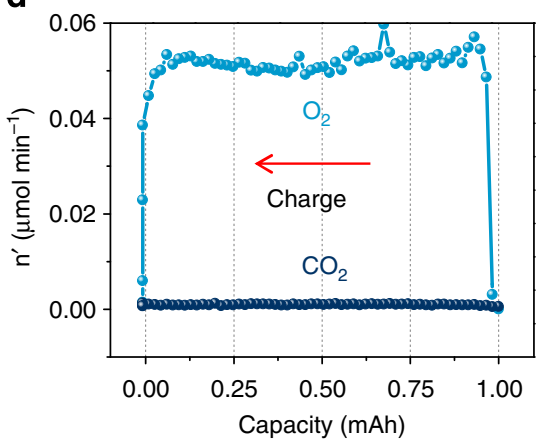

f

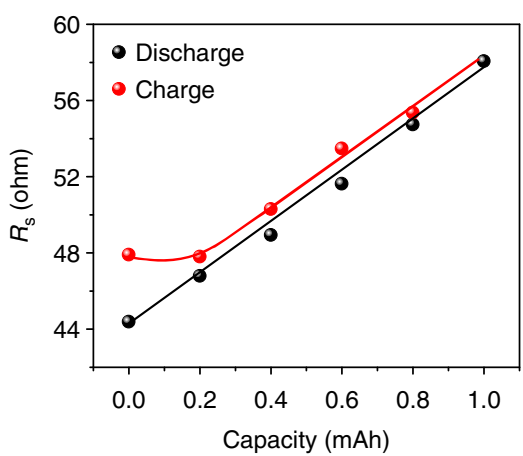

c

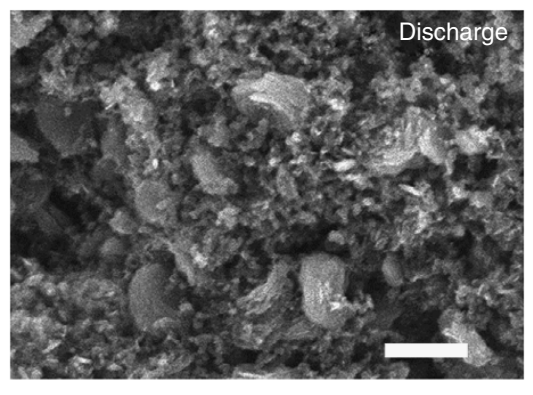

e

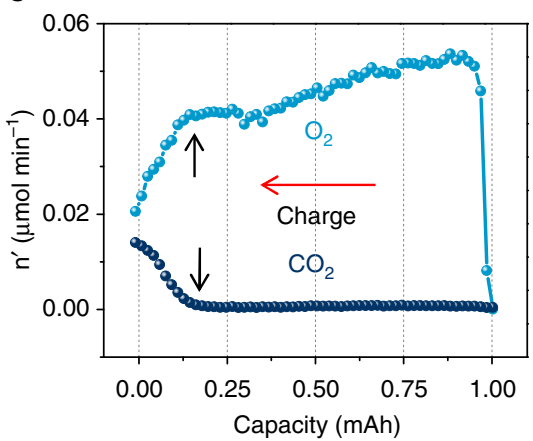

g

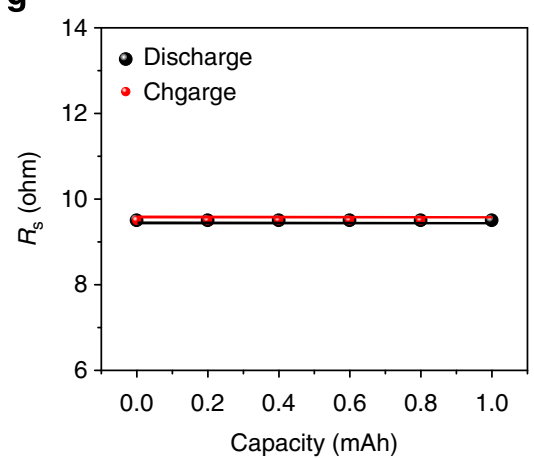

Figure 1 | In situ DEMS, SEM and impedance measurement. (a) A schematic presentation of the $\mathrm{Li}_{-} \mathrm{O}_{2}$ cell used in this study. (b) Galvanostatic discharge/charge profiles of the cells containing $0.5 \mathrm{M} \mathrm{LiNO}_{3}$-DME (blue) and $1 \mathrm{M}$ LiTFSI-DME (black) electrolyte. (c) A top view SEM micrograph of the carbon cathode after $1 \mathrm{mAh}$ discharge of the cell containing $0.5 \mathrm{M} \mathrm{LiNO}_{3}$-DME electrolyte. The scale bar indicates $500 \mathrm{~nm}$. (d) In situ DEMS result of the cell containing $0.5 \mathrm{M} \mathrm{LiNO}_{3}$-DME electrolyte. No $\mathrm{CO}_{2}$ evolution is detected during the entire charging process. (e) In situ DEMS result of the cell containing $1 \mathrm{M} \mathrm{LiTFSI-DME} \mathrm{electrolyte.} \mathrm{Significant} \mathrm{amount} \mathrm{of} \mathrm{CO}_{2}$ evolution is detected at the end of charging process. (f) The electrolyte resistance $\left(R_{\mathrm{s}}\right)$ of the cell containing $0.5 \mathrm{M} \mathrm{LiNO}_{3}$-DME electrolyte measured as a function of discharge and charge capacity. $(\mathbf{g})$ The $R_{\mathrm{s}}$ of the cell containing $1 \mathrm{M}$ LiTFSI-DME electrolyte measured as a function of discharge and charge capacity.

experiments. A linear sweep voltammetry measurement was performed for the cell containing $0.5 \mathrm{M} \mathrm{LiNO}_{3}$-DME under argon (Ar) gas environment (Supplementary Fig. 4a). A clear oxidation peak was observed at the potential near $3.6 \mathrm{~V}$, which suggests that an oxidation reaction takes place on the carbon surface. The product of this oxidation reaction was revealed by the 
complementary in situ DEMS results (Supplementary Fig. 4b), which confirms the evolution of $\mathrm{NO}$ gas at the potential of the oxidation peak in the linear sweep voltammetry. This indicates that the origin of the peak near $3.6 \mathrm{~V}$ is the oxidation of surface compound(s) containing $\mathrm{N}$ and $\mathrm{O}$. The existence of this surface compound(s) (we call this as surface layer) on carbon cathode is further evidenced by N1s X-ray photoelectron spectroscopy (XPS) analysis (Supplementary Fig. 4c). The XPS data show a peak at binding energy of $\sim 406 \mathrm{eV}$, which corresponds to $\mathrm{NO}_{\mathrm{x}}$ species ${ }^{17}$. It should be noted that the mixtures of glymes and lithium salts have been well known to form ionic associations (solvates), which often contain crystalline phases ${ }^{18,19}$. Among various anions, the $\mathrm{NO}_{3}^{-}$forms very strong ionic association with $\mathrm{DME}^{18-20}$. The surface layer containing $\mathrm{NO}_{\mathrm{x}}$ species on the carbon is, therefore, believed to be the solvate of $\mathrm{LiNO}_{3}$ and DME (such as contact ion pair between a DME molecule and $\mathrm{Li}^{+}$and $\left.\mathrm{NO}_{3}^{-}\right)^{18-20}$. It seems the surface layer does not affect the oxidation of $\mathrm{Li}_{2} \mathrm{O}_{2}$ during the charging process of the $\mathrm{Li}-\mathrm{O}_{2}$ cells as shown by the DEMS results of a $\mathrm{Li}-\mathrm{O}_{2}$ cell containing $0.5 \mathrm{M}$ $\mathrm{LiNO}_{3}$-DME electrolyte (Supplementary Fig. 5). There was no $\mathrm{NO}$ gas evolution at the oxidation potential of the $\mathrm{NO}_{\mathrm{x}}$ species during the charging process of the $\mathrm{Li}-\mathrm{O}_{2}$ cell.

The N1s XPS spectra of the carbon cathode after discharge process give more insights into the role of the $\mathrm{LiNO}_{3}-\mathrm{DME}$ solvate. The carbon cathode was pretreated with $\mathrm{LiNO}_{3}-\mathrm{DME}$ solvate, and $1 \mathrm{M}$ LiTFSI-DME was used as the electrolyte for the $\mathrm{Li}-\mathrm{O}_{2}$ cell (Supplementary Fig. 6). The XPS result in Fig. 2a shows a strong new peak at $\sim 398 \mathrm{eV}$ in addition to the $\mathrm{NO}_{\mathrm{x}}$ peak at $\sim 406 \mathrm{eV}$. The characteristic peak at $\sim 398 \mathrm{eV}$ of carbon is well known as the binding energy of the N1s in Pyridinic structure ${ }^{21-24}$. The existence of the Pyridinic structure, therefore, evidences the doping of nitrogen into carbon cathode during discharge process. Further, since the carbon in contact with the solvate at the open circuit voltage only shows $\mathrm{NO}_{\mathrm{x}}$ species on the surface (Supplementary Fig. 4), the formation of the Pyridinic structure is most likely driven by electrochemical process during the discharge of the cell. This also implies that the $\mathrm{NO}_{\mathrm{x}}$ species of the surface layer is used as the source of nitrogen. The nitrogen doping of carbon, which typically takes place by the interaction of $\mathrm{N}$-containing molecules with oxygenated groups on carbon (such as $-\mathrm{OOH},=\mathrm{O},-\mathrm{OH}$ ) and subsequent transformation into Pyrrolic or Pyridinic structures, leads to the loss of active sites on carbon surface ${ }^{21,25}$. The reaction between the solvate and active sites of carbon cathode in $\mathrm{Li}-\mathrm{O}_{2}$ cells, therefore, deactivates the carbon against parasitic reactions ${ }^{26}$. This is supported by the DEMS results (Supplementary Fig. 6b) showing less amount of
$\mathrm{CO}_{2}$ evolution when the carbon cathode is treated with the solvate. To completely eliminate the $\mathrm{CO}_{2}$ evolution, however, the parasitic reactions involved with electrolytes should be suppressed as well. Previous work shows that the formation of carbonates (resulting from the decomposition of electrolyte solvent) is significantly hindered when inert materials, such as nanoporous $\mathrm{Au}$ or $\mathrm{TiC}^{7,14}$, are used as the cathode. Further, the hydrophilicity of carbon is reported to be a governing parameter for the $\mathrm{CO}_{2}$ evolution ${ }^{9}$. These suggest that the carbon in the cathode is involved with the parasitic reactions to decompose the electrolytes and the surface functional groups of carbon play a critical role for the parasitic reactions. We used the carbon isotope $\left({ }^{13} \mathrm{C}\right)$ as the cathode to investigate the carbon's role for the decomposition of electrolyte solvent using DEMS measurements. Two cells were prepared using $1 \mathrm{M}$ LiTFSI-DME as an electrolyte: one has cathode of pristine ${ }^{13} \mathrm{C}$ and the other has ${ }^{13} \mathrm{C}$ pretreated with $\mathrm{LiNO}_{3}$-DME solution. The DEMS results evidence that the pretreated cathode evolves less amount of $\mathrm{CO}_{2}$ originated from both electrolyte $\left({ }^{12} \mathrm{CO}_{2}\right.$ in Supplementary Fig. 7a) and cathode $\left({ }^{13} \mathrm{CO}_{2}\right.$ in Supplementary Fig. 7b). This is in good agreement with previous work and also confirms the effect of solvate surface layer on the deactivation of carbon surface against parasitic reactions for electrolyte decomposition 7,14 . It is noted that the amount of the solvate on pretreated ${ }^{13} \mathrm{C}$ cathode was not enough to completely eliminate the $\mathrm{CO}_{2}$ evolution. To study the effect of solvate amount on the elimination of $\mathrm{CO}_{2}$ evolution, we preloaded the solvate on a glass filter (GF) separator before assembling the cells.

As mentioned above, the solvate of $\mathrm{LiNO}_{3}$-DME forms solid phase ionic association. When the solvate was deposited in GF, irregular solid particles were observed at the space between glass fibres (Supplementary Fig. 8). The composition of the solvate was measured using FTIR spectroscopy, which confirms the existence of $\mathrm{LiNO}_{3}$ and DME molecules (Supplementary Fig. 9). The discharge and charge profiles of the $\mathrm{Li}-\mathrm{O}_{2}$ cell containing the preloaded GF separator with $1 \mathrm{M}$ LiTFSI-DME electrolyte (Supplementary Fig. 10a) are very similar to those of the cell

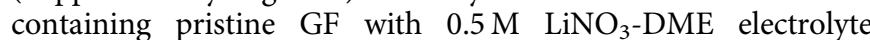
(shown in Fig. 1b). The DEMS results show very small amount of $\mathrm{CO}_{2}$ evolution (Supplementary Fig. 10b) at the end of charge process. This suggests that the amount of the solvate on the preloaded GF was enough to significantly suppress the $\mathrm{CO}_{2}$ evolution. The N1s XPS spectra of the carbon cathode after discharge process evidence the existence of both Pyridinic structure and the surface layer containing $\mathrm{NO}_{\mathrm{x}}$ species as shown in Fig. 2b. Relatively stronger intensity of $\mathrm{NO}_{\mathrm{x}}$ peak
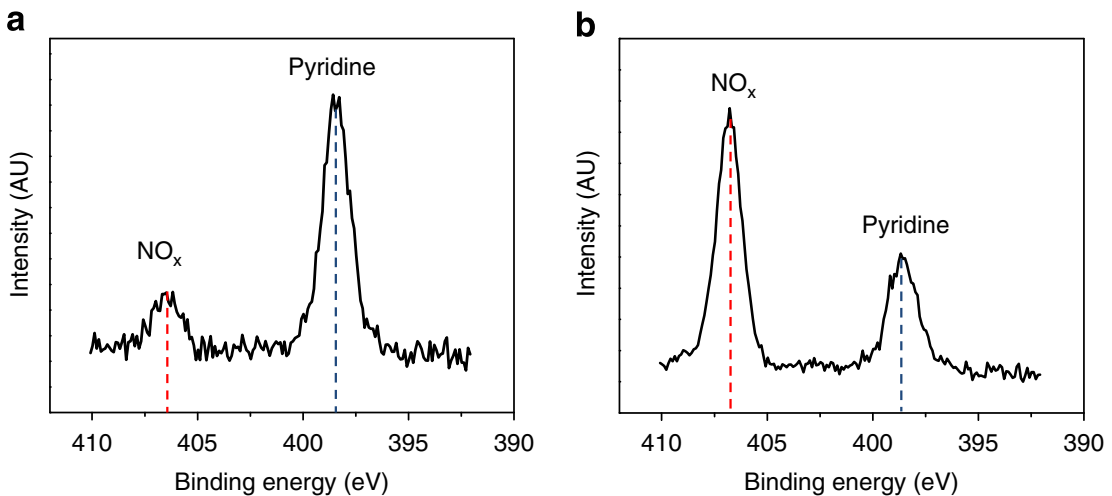

Figure 2 | XPS on carbon cathode. (a) The N1s XPS result of the carbon cathode after discharge process. The carbon cathode was pretreated with $0.5 \mathrm{M} \mathrm{LiNO}_{3}$-DME to deposit the surface layer. LiTFSI-DME $(1 \mathrm{M})$ was used as the electrolyte. (b) The N1s XPS result of the carbon cathode after discharge process of the cell containing preloaded GF separator. The solvate of $\mathrm{LiNO}_{3}-\mathrm{DME}$ was preloaded into GF before assembly of the cell. LiTFSI-DME $(1 \mathrm{M})$ was used as the electrolyte. The red and blue dotted lines correspond to the $\mathrm{NO}_{x}$ species and Pyridinic structure, respectively. 
implies that the formation of surface layer continues during discharge process if the supply of the solvate is not limited. This is in good agreement with the linear increase in $R_{\mathrm{s}}$ during discharge cycle as shown in Fig. 1f. The hysteresis in $R_{\mathrm{s}}$ at the end of charge cycle in Fig. If is attributed to the loss of ionic species by forming Pyridinic structure and the residue of the solvate on carbon surface. This is supported by the XPS result after discharge and charge processes (Supplementary Figs 11 and 12).

Mixed electrolytes. Generally speaking, solvents with high boiling temperature and/or low vapor pressure are envisioned as ideal when one considers the cycle life and the safety of $\mathrm{Li}-\mathrm{O}_{2}$ cells. As DME has relatively low boiling temperature $\left(85^{\circ} \mathrm{C}\right)$, we tested whether the deactivation of carbon with $\mathrm{LiNO}_{3}-\mathrm{DME}$ solvate is still possible in the presence of high boiling point cosolvent(s).
We tested two mixed electrolyte systems: (a) $\mathrm{LiNO}_{3}$-DME and $\mathrm{LiNO}_{3}-\mathrm{N}, \mathrm{N}$-dimethylacetamide (DMAc, boiling point (b.p.) of $165^{\circ} \mathrm{C}$ ) and (b) $\mathrm{LiNO}_{3}$-DME and $\mathrm{LiNO}_{3}$-tetraethylene glycol dimethyl ether (tetraglyme, b.p. of $275^{\circ} \mathrm{C}$ ). Strikingly, the results indicated that the deactivation of carbon took place in the mixed electrolytes and the evolution of $\mathrm{CO}_{2}$ was completely eliminated. Figure $3 \mathrm{a}$ shows the discharge/charge profiles of a $\mathrm{Li}-\mathrm{O}_{2}$ cell containing a 50/50 (wt/wt) mixture of $1 \mathrm{M} \mathrm{LiNO}_{3}$-DME and $1 \mathrm{M}$ $\mathrm{LiNO}_{3}$-DMAc. The discharge/charge profiles of the mixed electrolyte were similar to those with single electrolyte of $1 \mathrm{M} \mathrm{LiNO}_{3}-$ DMAc (Supplementary Fig. 13a). However, DEMS results showed clear difference in gas evolution. The $\mathrm{Li}-\mathrm{O}_{2}$ cell containing single electrolyte of $\mathrm{LiNO}_{3}$-DMAc (as shown in Supplementary Fig. 13b) evolved fair amount of $\mathrm{CO}_{2}$ and the experiment with isotope carbon showed the origin of $\mathrm{CO}_{2}$ was both the electrolyte and the cathode (Supplementary Fig. 13c,d). In contrast, the DEMS result in Fig. $3 \mathrm{~b}$ indicates the complete elimination of $\mathrm{CO}_{2}$ a

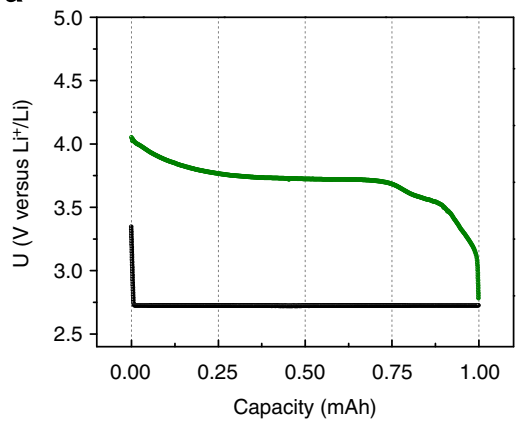

C

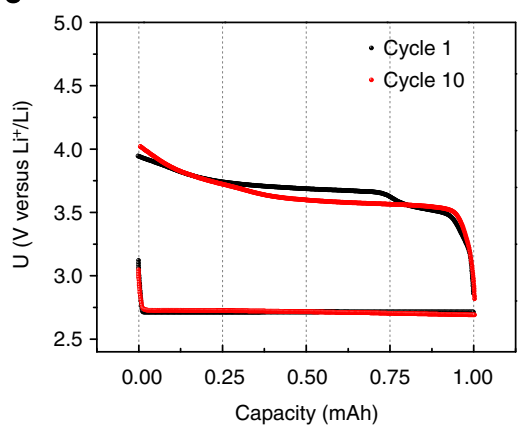

e

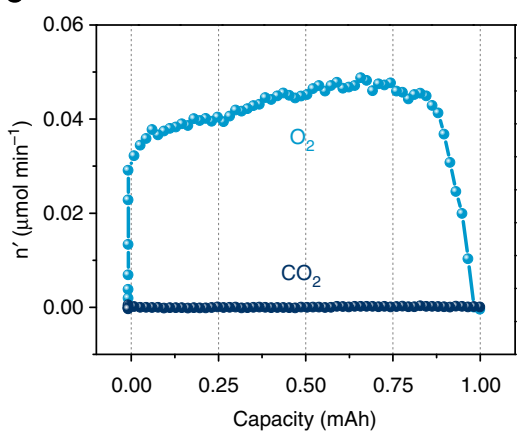

b

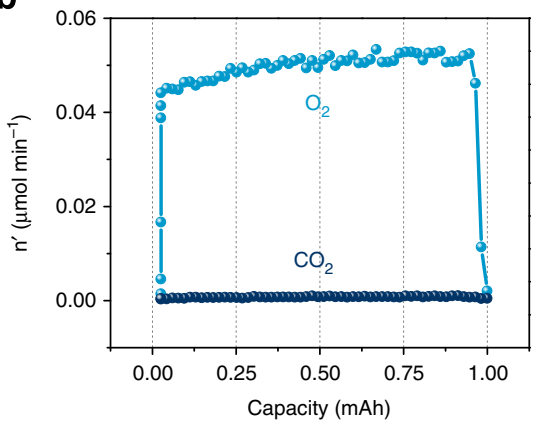

d

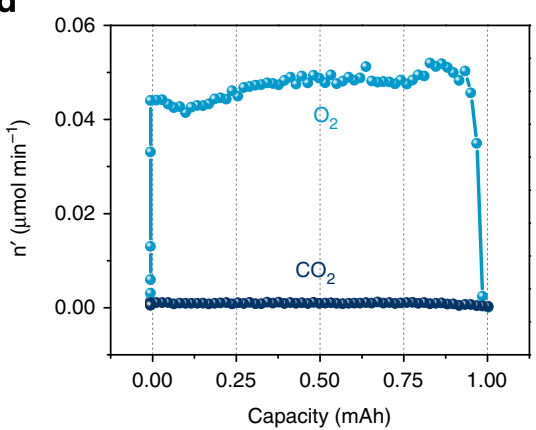

f

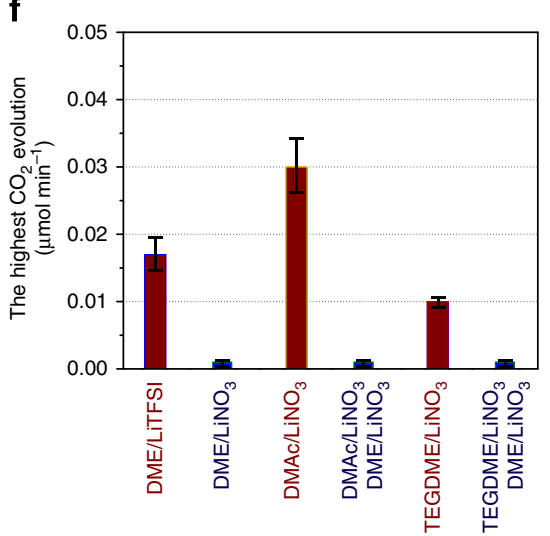

Figure 3 | $\mathbf{L i}-\mathbf{O}_{\mathbf{2}}$ cells with mixed electrolytes. (a) Galvanostatic discharge/charge profiles and (b) in situ DEMS data of the cell containing a mixed electrolyte of $50 / 50$ (wt/wt) $1 \mathrm{M} \mathrm{LiNO}_{3}$-DME and $1 \mathrm{M} \mathrm{LiNO}_{3}-\mathrm{DMAc}$. (c) The first (black) and tenth (red) galvanostatic discharge/charge profiles of the cell containing a mixed electrolyte of 50/50 (wt/wt) $1 \mathrm{M} \mathrm{LiNO}_{3}$-DME and $0.5 \mathrm{M} \mathrm{LiNO}_{3}$-tetraglyme. (d) In situ DEMS data of the first charge cycle of the cell in c. (e) In situ DEMS data of the tenth charge cycle of the cell in c. (f) The peak $\mathrm{CO}_{2}$ evolution ( $\mu$ mol min ${ }^{-1}$ ) of the cells containing various electrolytes. The results from five cells of each electrolyte were averaged for the statistics. 
evolution when mixed electrolyte was used. This evidences that the solvate of $\mathrm{LiNO}_{3}$-DME plays its role to deactivate the carbon even in the mixed electrolyte.

The mixing composition of two electrolytes was found to be critical for effective elimination of $\mathrm{CO}_{2}$ evolution (Supplementary Fig. 14). In fact, for DMAc, the mixed electrolyte with less than 50 wt\% of $\mathrm{LiNO}_{3}$-DME leads to $\mathrm{CO}_{2}$ evolution (Supplementary Fig. 14). This implies that to maintain the solvate structure of $\mathrm{LiNO}_{3}$-DME in mixed electrolyte solution is essential for the eliminating $\mathrm{CO}_{2}$ evolution. The nature (such as solubility) and the amount of cosolvent(s), therefore, need to be carefully controlled to avoid the destruction of the solvate. We were also able to operate the $\mathrm{CO}_{2}$ evolution free $\mathrm{Li}-\mathrm{O}_{2}$ cells using a mixed electrolyte of $50 / 50(\mathrm{wt} / \mathrm{wt}) \quad 0.5 \mathrm{M} \mathrm{LiNO}_{3}$-tetraglyme and $1 \mathrm{M}$ $\mathrm{LiNO}_{3}$-DME as well (Fig. 3c-e and Supplementary Fig. 15). We summarized the peak $\mathrm{CO}_{2}$ evolution from mixed electrolytes in Fig. 3f, which suggests that the effect of $\mathrm{LiNO}_{3}$-DME solvate on the deactivation of carbon cathode is general. Finally, we confirmed that the elimination of $\mathrm{CO}_{2}$ evolution is maintained during multiple discharge/charge cycles. Figure $3 c$,e shows discharge/charge profiles and gas evolutions of the first and tenth cycles, respectively, of the cell containing mixed electrolyte of 50/50 (wt/wt) $1 \mathrm{M} \mathrm{LiNO}_{3}$-DME and $0.5 \mathrm{M} \mathrm{LiNO}_{3}$-tetraglyme. It is clear that no $\mathrm{CO}_{2}$ evolution was observed even after tenth cycle of the $\mathrm{Li}-\mathrm{O}_{2}$ cell. The N1s XPS results (not shown here) of the cathode after tenth cycle indicate the formation of Pyridinic structure. It should be noted that the $\mathrm{O}_{2}$ evolution profile of the tenth charge cycle (Fig. 3e) shows reduced amount of $\mathrm{O}_{2}$ evolution compared with the first cycle. This implies that other parasitic reactions that lower the oxygen efficiency still exist during the cycles, even though the deactivated cathode eliminates the $\mathrm{CO}_{2}$ evolution.

\section{Discussion}

This work demonstrates the elimination of $\mathrm{CO}_{2}$ evolution from $\mathrm{Li}-\mathrm{O}_{2}$ cells with carbon cathode by mitigating the reactivity of carbon. The surface layer of $\mathrm{LiNO}_{3}$-DME solvate on carbon deactivates the carbon surface through the electrochemical nitrogen doping of carbon (during the operation of the $\mathrm{Li}-\mathrm{O}_{2}$ cells), which hinders the parasitic reactions to evolve the $\mathrm{CO}_{2}$. It is noted that the nitrogen doping is a result of the reaction between active sites on carbon and the solvate but not a sufficient requirement for the elimination of $\mathrm{CO}_{2}$ evolution. Ex situ $\mathrm{N}$-doped carbon, for example, may still contain defects that are active to parasitic reactions, and thus leads to $\mathrm{CO}_{2}$ evolution during the charge process of $\mathrm{Li}-\mathrm{O}_{2}$ cells. The elimination of $\mathrm{CO}_{2}$ evolution works for mixed electrolytes (as long as the cosolvents do not disturb the solvate structure of $\mathrm{LiNO}_{3}$-DME) and for multiple discharge/charge cycles. This work motivates more active research on managing undesired nature of commonly available carbon, which will help keep the promise of the high specific energy of the $\mathrm{Li}-\mathrm{O}_{2}$ cells.

\footnotetext{
Methods

Materials and cathode preparation. Battery grade DME, tetraglyme and DMAC solvents were purchased from Novolyte Corp. and dried over $0.4 \mathrm{~nm}$ molecular sieves. $\mathrm{LiNO}_{3}$ and LiTFSI (Novolyte Corp.) salts were dried under high vacuum at $150^{\circ} \mathrm{C}$ for $12 \mathrm{~h}$. The water content of solvent and salts is less than 10 p.p.m. measured by Karl Fischer titration. The electrolytes were prepared in an Ar-filled glove box $\left(<0.1\right.$ p.p.m. $\mathrm{O}_{2}$ and $\left.\mathrm{H}_{2} \mathrm{O}\right)$. The pure Li metal was purchased from FMC and used as received. The $\mathrm{GF}\left(\mathrm{GF} / \mathrm{C}\right.$, Whatman) was dried under $150^{\circ} \mathrm{C}$ vacuum oven for $24 \mathrm{~h}$. Ketjenblack (KB) carbon (AkzoNobel) or ${ }^{13} \mathrm{C}$ carbon (Cambridge isotope laboratories, Inc.) was well mixed with a $60 \mathrm{wt} \%$ PTFE (Sigma-Aldrich) binder in water solution and subsequently coated on a Toray carbon paper (TGP$\mathrm{H}-030$ ). The carbon cathodes were dried under $150^{\circ} \mathrm{C}$ vacuum oven for $24 \mathrm{~h}$ and transferred to the Ar-filled glove box before the cell fabrication.
}

Fabrication of $\mathbf{L i}-\mathbf{O}_{\mathbf{2}}$ Cells. Cell fabrication was done in an Ar-filled glove box (<0.1 p.p.m. $\mathrm{O}_{2}$ and $\mathrm{H}_{2} \mathrm{O}$ ). Fabrication of $\mathrm{Li}-\mathrm{O}_{2}$ cells began with placing $11 \mathrm{~mm}$ diameter and $250-\mu \mathrm{m}$ thick $\mathrm{Li}$ disc on an anode side current collector. The GF (GF/C, Whatman) was then placed on the Li disc. An electrolyte solution $(65 \mu \mathrm{l})$ was injected into the GF followed by placing a $\mathrm{KB}$ or ${ }^{13} \mathrm{C}$ carbon cathode and a spacer for head volume of the DEMS cell. Finally, a cathode current collector that has inlet and outlet holes for oxygen gas was placed on top of cathode to complete the cell fabrication.

Characterization methods. The nanostructure of the KB carbon surface was observed by SEM (Hitachi S-4700) with field emission gun electron microscope. For transferring the $\mathrm{KB}$ cathode samples to SEM chamber, the $\mathrm{Li}-\mathrm{O}_{2}$ cells were disassembled in an Ar-filled glove box after discharge or discharge-charge process. The KB cathodes were stored in an Ar-filled plastic carrier. The sample was transferred to the SEM anti-chamber and immediately evacuated the chamber (less than $5 \mathrm{~s}$ ). The surface of cathodes was investigated by XPS (An Omicron, ESCA probe spectrometer) using monochromatic Al K-alpha radiation $(1,486.6 \mathrm{eV})$ with $200 \mu \mathrm{m}$ spot size throughout and charge neutralization under vacuum of $\sim 10^{-10}$ Torr. The XPS samples were prepared in an Ar-filled glove box after discharge or discharge-charge process and transferred with an Ar-filled carrier. Surface atomic concentration percent $\left(C_{i}\right)$ was estimated using the equation $C_{i}=I_{i} / \sigma_{i} / \Sigma I_{n} / \sigma_{n}$, where $I$ is the peak area and $\sigma$ the energy corrected photoionization cross-section of the $i$ th element. This calculation assumed uniform composition with depth. Electrochemical measurements were performed using a BioLogic VMP3 Multichannel Workstation. The details of DEMS system were described elsewhere ${ }^{12}$. The X-ray diffraction analysis of the $\mathrm{Li}_{2} \mathrm{O}_{2}$ crystals was performed using a Bruker D8 DISCOVER GADDS Series.

\section{References}

1. Girishkumar, G., McCloskey, B., Luntz, A. C., Swanson, S. \& Wilcke, W. Lithium-air battery: promise and challenges. J. Phys. Chem. Lett. 1, 2193-2203 (2010).

2. Bruce, P. G., Freunberger, S. A., Hardwick, L. J. \& Tarascon, J. M. Li-O 2 and Li-S batteries with high energy storage. Nat. Mater. 11, 19-29 (2012).

3. Abraham, K. M. \& Jiang, Z. A polymer electrolyte-based rechargeable lithium/ oxygen battery. J. Electrochem. Soc. 143, 1-5 (1996).

4. Christensen, J. et al. A critical review of Li/Air batteries. J. Electrochem. Soc. 159, R1-R30 (2011).

5. Oh, S. H., Black, R., Pomerantseva, E., Lee, J. H. \& Nazar, L. F. Synthesis of a metallic mesoporous pyrochlore as a catalyst for lithium- $\mathrm{O}_{2}$ batteries. Nat. Chem. 4, 1004-1010 (2012).

6. McCloskey, B. D. et al. Limitations in rechargeability of $\mathrm{Li}_{-} \mathrm{O}_{2}$ batteries and possible origins. J. Phys. Chem. Lett. 3, 3043-3047 (2012).

7. Peng, Z., Freunberger, S. A., Chen, Y. \& Bruce, P. G. A reversible and higherrate $\mathrm{Li}-\mathrm{O}_{2}$ battery. Science 337, 563-566 (2012)

8. Lu, Y.-C. et al. Lithium-oxygen batteries: bridging mechanistic understanding and battery performance. Energy Environ. Sci. 6, 750-768 (2013).

9. Ottakam Thotiyl, M. M., Freunberger, S. A., Peng, Z. \& Bruce, P. G. The carbon electrode in nonaqueous Li-O2 cells. J. Am. Chem. Soc. 135, 494-500 (2013).

10. Gallant, B. M. et al. Chemical and morphological changes of $\mathrm{Li}-\mathrm{O}_{2}$ battery electrodes upon cycling. J. Phys. Chem. C 116, 20800-20805 (2012).

11. Laoire, C. O., Mukerjee, S., Abraham, K. M., Plichta, E. J. \& Hendrickson, M. A Influence of nonaqueous solvents on the electrochemistry of oxygen in the rechargeable lithium-air battery. J. Phys. Chem. C 114, 9178-9186 (2010).

12. McCloskey, B. D., Bethune, D. S., Shelby, R. M., Girishkumar, G. \& Luntz, A. C. Solvents' critical role in nonaqueous lithium-oxygen battery electrochemistry. J. Phys. Chem. Lett. 2, 1161-1166 (2011).

13. Wu, Y. P., Rahm, E. \& Holze, R. Carbon anode materials for lithium ion batteries. J. Power Sources 114, 228-236 (2003).

14. Ottakam Thotiyl, M. M. et al. A stable cathode for the aprotic Li-O battery. Nat. Mater. 12, 1050-1056 (2013).

15. Horstmann, B. et al. Rate-dependent morphology of $\mathrm{Li} 2 \mathrm{O} 2$ growth in $\mathrm{Li}-\mathrm{O}_{2}$ batteries. J. Phys. Chem. Lett. 4, 4217-4222 (2013).

16. Xu, J.-J., Wang, Z.-L., Xu, D., Zhang, L.-L. \& Zhang, X.-B. Tailoring deposition and morphology of discharge products towards high-rate and long-life lithiumoxygen batteries. Nat. Commun. 4, 2438 (2013).

17. Adenier, A. et al. Grafting of nitrophenyl groups on carbon and metallic surfaces without electrochemical induction. Chem. Mater. 17, 491-501 (2005).

18. Henderson, W. A. Glyme-lithium salt phase behavior. J. Phys. Chem. B 110, 13177-13183 (2006).

19. Henderson, W. A. Crystallization kinetics of glyme - LiX and PEO - LiX polymer electrolytes. Macromolecules 40, 4963-4971 (2007).

20. Henderson, W. A., Brooks, N. R. \& Smyrl, W. H. Polymeric [Li(NO3)(monoglyme)]n. Acta Crystallogr. Sect. E 58, m500-m501 (2002).

21. Wang, H., Maiyalagan, T. \& Wang, X. Review on recent progress in nitrogendoped graphene: synthesis, characterization, and its potential applications. ACS Catalysis 2, 781-794 (2012). 
22. Peng, H. et al. High performance Fe- and N-doped carbon catalyst with graphene structure for oxygen reduction. Sci. Rep. 3, 1765 (2013).

23. Wu, Z.-S., Ren, W., Xu, L., Li, F. \& Cheng, H.-M. Doped graphene sheets as anode materials with superhigh rate and large capacity for lithium ion batteries. ACS Nano 5, 5463-5471 (2011).

24. Qu, L., Liu, Y., Baek, J.-B. \& Dai, L. Nitrogen-doped graphene as efficient metalfree electrocatalyst for oxygen reduction in fuel cells. ACS Nano 4, 1321-1326 (2010).

25. Mou, Z. et al. Forming mechanism of nitrogen doped graphene prepared by thermal solid-state reaction of graphite oxide and urea. Appl. Surf. Sci. 258, 1704-1710 (2011).

26. Xiao, J. et al. Hierarchically porous graphene as a lithium-air battery electrode. Nano Lett. 11, 5071-5078 (2011).

\section{Acknowledgements}

We are thankful for all the support from Battery 500 team members in IBM Almaden Research Center. S.J.K. thanks to Dr Dong Wook Kim and Dr Nagaphani Aetukuri for useful discussion and spectroscopy measurements.

\section{Author contributions}

S.J.K. performed sample fabrication and characterization. S.J.K., T.M. and S.N. prepared the electrolytes. S.J.K. and H.-C.K. designed the research project, analysed the data and prepared the manuscript. S.J.K., T.M., S.N., W.W. and H.-C.K. contributed to the discussion of the results.

\section{Additional information}

Supplementary Information accompanies this paper at http://www.nature.com/ naturecommunications

Competing financial interests: The authors declare no competing financial interests.

Reprints and permission information is available online at http://npg.nature.com/ reprintsandpermissions/

How to cite this article: Kang, S. J. et al. Deactivation of carbon electrode for elimination of carbon dioxide evolution from rechargeable lithium-oxygen cells. Nat. Commun. 5:3937 doi: 10.1038/ncomms4937 (2014). 